\title{
Recent Benthic Foraminifera in Surficial Sediment off Kodiyakarai, Palk Bay, Tamilnadu, East Coast of India
}

\author{
M. Suresh Gandhi, K. Kasilingam, M. Raja and T. Arumugam \\ Department of Geology, University of Madras \\ Guindy Campus, Chennai - 600 025, India \\ Email: msureshgandhi@gmail.com
}

\begin{abstract}
Various hydrographic parameters such as temperature, salinity, oxygen content as well as bathymetry and substrate condition affect the distribution of foraminifera. However, it has not been convincingly shown that these are the sole factors influencing the distribution of foraminiferal populations in the shelf environment. Recent benthic foraminifera in surficial sediment off Kodiyakarai, Palk Bay, Tamilnadu, east coast of India has been studied. In total, 48 species belonging to 14 families and 22 genus were identified. The following species are widely distributed in the offshore samples, namely Ammonia beccarii, A. dentata, A.tepida, Asterorotalia trispinosa, Spiroloculina communis, Quinqueloculina elongatum, Q.lamarckiana, Q. seminulum, Triloculina trigonula, Elphidium crispum, Parallina hispidula, and Assilina ammonoides. The environmental parameters mainly sediment texture and salinity appear to govern the abundance distribution of foraminifera in this region. Live/ dead ratio in benthic population ranges between 0.7 and $4.39 \%$. It suggests a low rate of sedimentation in this region.
\end{abstract}

Keywords: Benthic Foraminifera, Environment, Off Kodiyakarai, Palk Bay

\section{Introduction}

Palk Bay is one among the five major sediment sinks of India. The study area off Kodiyakkarai is located in Palk Bay of Tamilnadu (Fig.1). The area is influenced by major drainage patterns of the River Cauvery, which transports large amounts of terrigenous sediments into shelf, producing coastal shoal. This part of the area is also located in a Sethusamudram canal project where intensive downslope sediment transport processes are observed. The study area is endangered with high siltation (Loveson et al., 1990; Gandhi, 1999; Jena et al., 2001; Mohan et al., 2000; Santhidevi and Rajamanickam, 2009; Kumar, et al., 2000; Sundararajan and Natesan, 2010). Foraminifera are sensitive even to subtle changes in ambient environmental conditions and, therefore, have emerged as potential tools for assessing any climatic/environmental changes. The east coast of India has prolific presence of foraminifera and a number of studies have been published on foraminiferal characteristics from this region particularly on taxonomy and distribution. However, literature is sparse and scattered in the present study area off Kodiyakarai and, therefore, it is most appropriate to study the foraminiferal distribution its relationship with modern environmental conditions. 


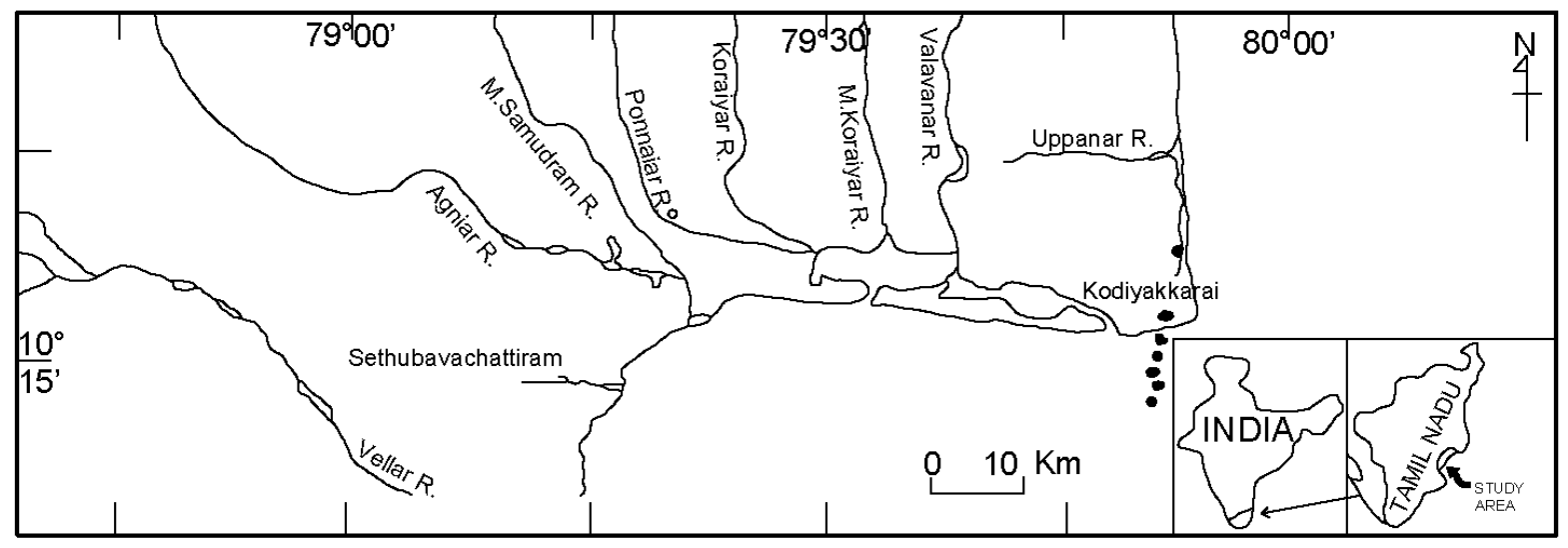

Fig.1: Location map of study area.

\section{Study Area}

Palk Bay, named after Sir Robert Palk (1717-1798), the then Governor of Madras Presidency (1755-1763), is situated in the southeast coast of India encompassing the sea between Point Calimere (Kodiyakarai) near Vedaranyam in the north and the northern shores of Mandapam to Dhanushkodi in the south. It is situated between Latitude $9^{\circ} 55^{\prime}-10^{\circ} 45^{\prime} \mathrm{N}$ and Longitude $78^{\circ} 58^{\prime}-79^{\circ} 55^{\prime} \mathrm{E}$. The Palk Bay itself is about $110 \mathrm{~km}$ long and is surrounded on the northern and western sides by the coastline of the State of Tamilnadu in the mainland of India. Palk Bay and Gulf of Mannar to its south are connected by a narrow passage called Pamban Strait, which is about $1.2 \mathrm{~km}$ wide and 3 to $5 \mathrm{~m}$ deep that separates the Island of Rameswaram from the mainland. The region between Nagapattinam and Adirampattinan 18 strandlines are identified. They vary in length from 100 to few Km. They are aligned EW, NW and SW, NNE SSW and SW-NE (Fig. 2). The hydrographic parameter of the Palk bay is shown in the Table-1.

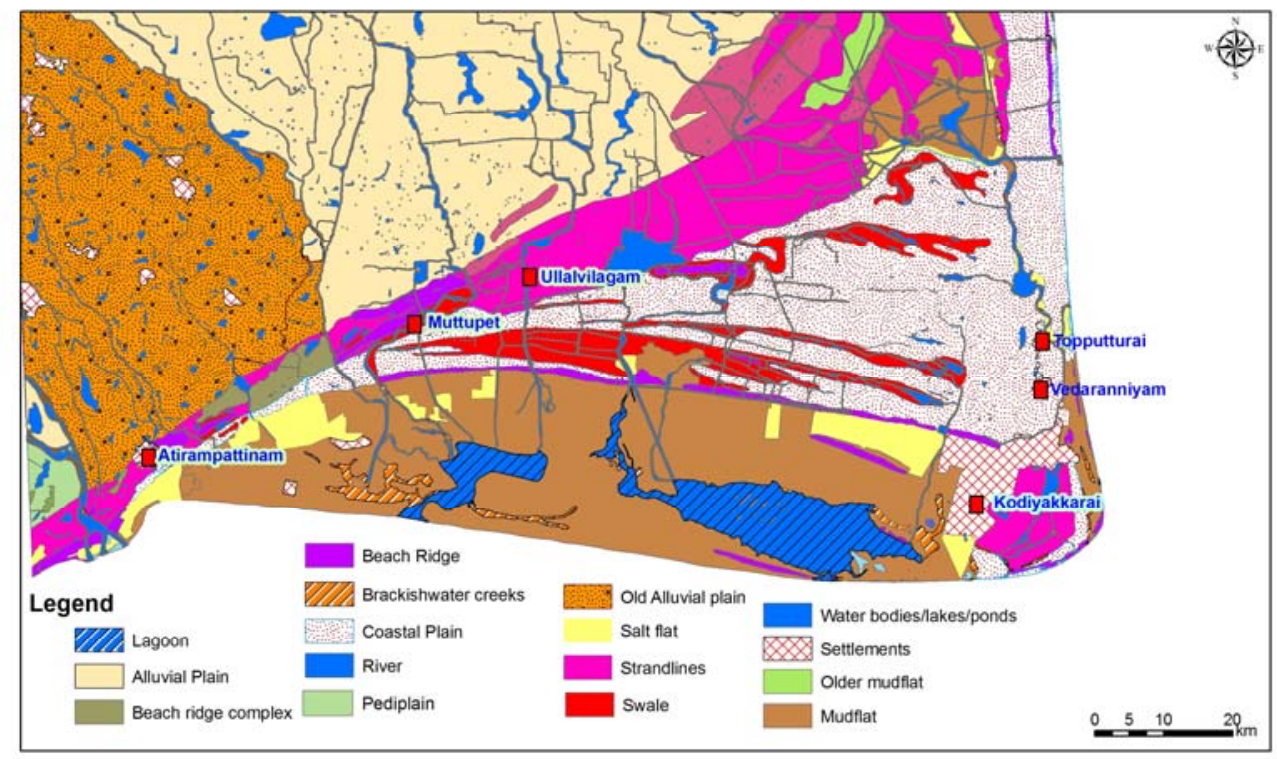

Fig.2: Geomorphological map of the study area. 
Table-1: Hydrographic parameters of Palk Bay.

\begin{tabular}{|l|l|l|}
\hline S.No. & Parameters & Range \\
\hline 1 & Temperature & $350 \mathrm{C}$ \\
\hline 2 & Salinity & $34.3 \mathrm{ppt}$ \\
\hline 3 & PH & 8.72 \\
\hline 4 & DO & $3.5 \mathrm{ml} / \mathrm{l}$ \\
\hline 5 & $\begin{array}{l}\text { Gross and Net primary } \\
\text { production }\end{array}$ & $0.67 \mathrm{mgC} / \mathrm{l} /$ day \\
\hline 6 & Rainfall & 909.7 \\
\hline 7 & Tides and currents & $0.41 \mathrm{msl}$ \\
\hline
\end{tabular}

\section{Methodology}

Surface sediment and water samples were collected at 7 locations off Kodiyakarai from water depths between 1.0 and $10 \mathrm{~m}$. Sediment samples were collected using grab sampler deploying both mechanized and country boats in the month of May, 2011. Sediment samples immediately after collection were preserved in a 10\% neutralized formaldehyde solutions, neatly labeled for further sample processing, analysis and foraminiferal separation (Walton, 1952). Calcium Carbonate was determined by volumetric method (Hutchinson and MeClennan, 1947). Organic carbon content is determined by the Walkey-Black method (1947), adopted and modified from Jackson (1958). For identification, classification of Loeblich and Tappan (1988) has been followed in the present work. Scanning electron micrographs of different views of all the foraminiferal species were obtained using a JOEL JSM 6530 model.

\section{Results and Discussion}

In the present study, 48 species belonging to 14 families and 22 genera were identified. The foraminiferal taxa belong to five Suborders such as TEXTULARIINA, MILIOLINA, LEGENINA, GLOBIGERININA and ROTALIINA. The total distribution of foraminifera is shown in Table-2. The genus Ammonia, Asterorotalia, Elphidium, Pararotalia predominate in the assemblages. The fine grained beach sediment contains less abundance of foraminifera.

The following species are widely distributed in the offshore samples, namely Ammonia beccarii, A. dentata, A. tepida, Asterorotalia trispinosa, Spiroloculina communis, Quinqueloculina elongatum, Q. lamarckiana, Q. seminulum, Triloculina trigonula, Elphidium crispum, Parallina hispidula, and Assilina ammonoides. The total numbers of species are high in water depths of 7.5 and $8.5 \mathrm{~m}$. The environmental parameters like sediment nature and water salinity may be the main factors influencing the abundance distribution of foraminifera in this region. Most of the species are rare in their occurrences. Reduced salinity plays a key role in inhibiting certain species in some near shore areas; however, turbulence and turbidity may be additional important factors. Fig. 3 shows the salinity gradient data by Lowmen (1949). 


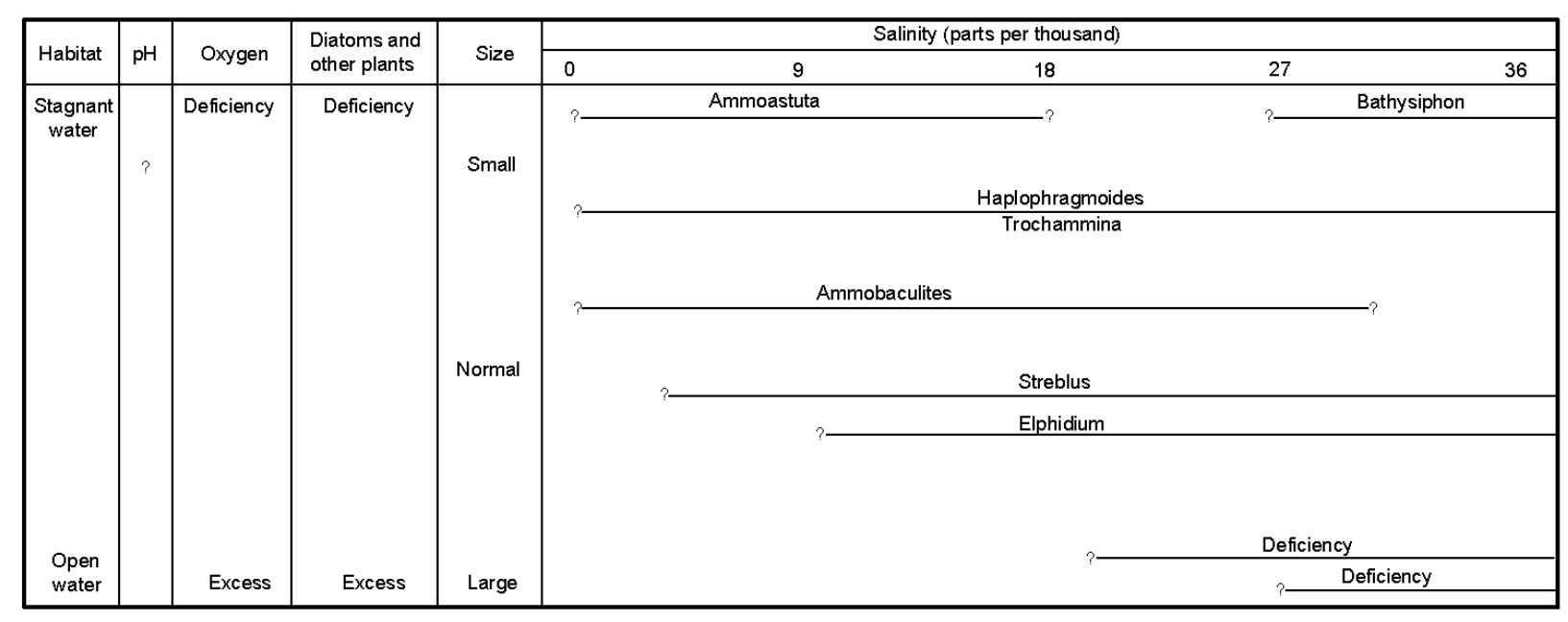

Fig.3: Assemblage and ecologic factors (adapted in part from data by Lowman, 1949).

\section{Distribution of Foraminiferal Species}

The Fig. 4 shows the pattern distribution of living foraminiferal species in the offshore region. The distribution of total living foraminiferal species is very less up to the depth of $5.5 \mathrm{~m}$, whereas it is slightly increased at depths between 5.5 and $8.5 \mathrm{~m}$. Due to the tidal fluctuation, and changing substrate, the diversity is also varied according to depths (Hayward, 1981). Sediment samples from the near shore region and inner shelf (maximum depth of $\sim 30 \mathrm{~m}$ ) yielded a high species diversity (Renata Szarek, et al., (2006). The near shore region was typified by species Quinqueloculina lamarckiana, Ammonia beccarii, Pararotalia nipponica and Elphidium crispum, all of which have been recorded from shallow waters worldwide (Murray, 1991; Nisha and Singh, 2012). Few tests of A. dentata with long, slender spines were observed, but only in the relatively deeper water sediment samples. A similar observation was also made by earlier workers (e.g. Ragothaman, 1974; Rajeshwara Rao, 1998; Nisha and Singh, 2012). A. dentata with short, blunt spines are more common in the near shore waters. The species Asterorotalia trispinosa is dominated in all the samples. Smaller sized foraminifera observed in some sampling locations may be due to the fine sediment texture.

\section{Live/Dead Ratio}

Live/dead ratio in benthic foraminiferal assemblages ranges between 0.7 and 4.39. It suggests a low rate of sedimentation in this region. The low rate of sedimentation prevailing in this part is in agreement with the findings of Paropkari (1979), Setty and Nigam (1982) and Paropkari et al., (1993) who reported low organic matter in the places of low sedimentation rate. The organic matter is also found to be low in this area. According to Demaison and Moore (1980), relatively higher values of organic matter content in the vicinity of the coast is related to high input of terrigenous matter. 
Open access e-Journal

Earth Science India, eISSN: $0974-8350$

Vol. 7 (III), July, 2014, pp. 73 - 88

http://www.earthscienceindia.info/

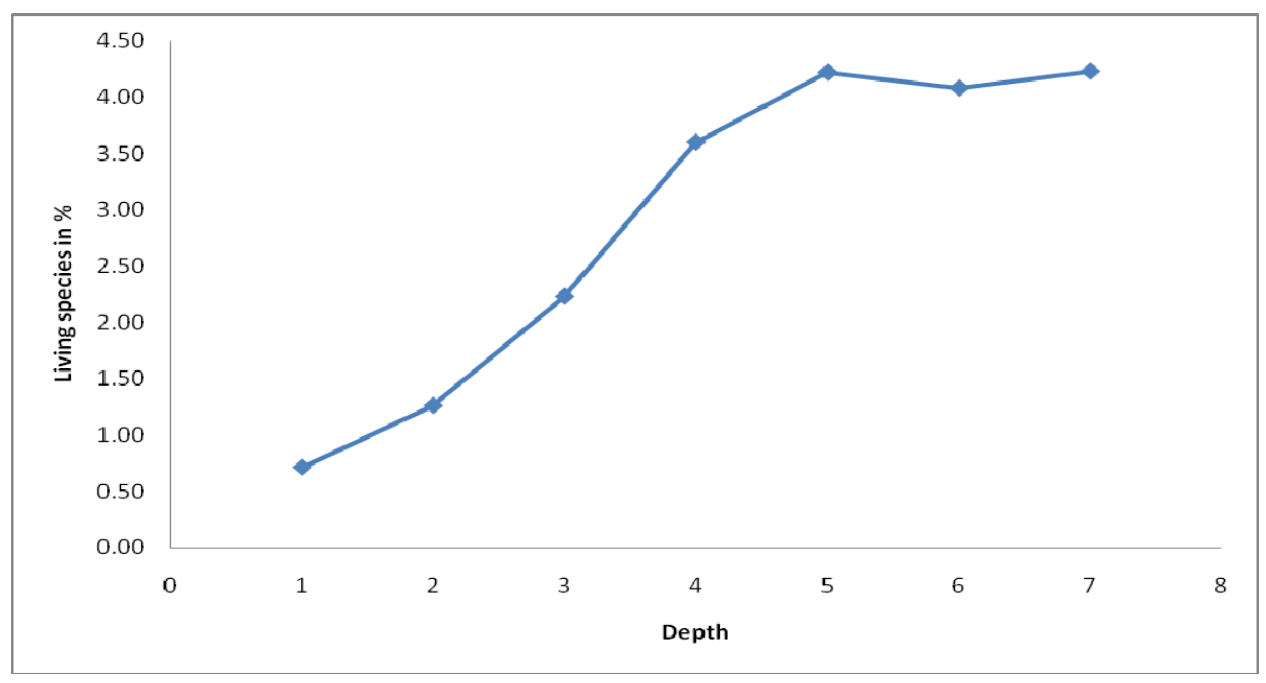

Fig.4: Distribution of living foraminifera in percentage.

\section{Ecology of Foraminifera}

The distribution and abundance of living foraminifera are controlled by a number of natural factors which include temperature, salinity, water depth, nutrients, sediment substrate, dissolved oxygen content, organic matter etc. The results of ecological parameters and living/dead species are shown in Table-3. Kodiyakarai is found to be highly favourable for the foraminifera; probably because of protected environment due to the impact of long shore current. In spite of lesser water depth and more protective in nature, it may also be ascribed to the wider undisturbed contact with open sea.

\section{Temperature}

The present study does not show much variation in temperature at different depths in the offshore stations $\left(29^{\circ} \mathrm{C}\right.$ to $\left.30^{\circ} \mathrm{C}\right)$. This is due to the fact that the stations are located in the nearshore environment within the depth of $15 \mathrm{~m}$. From the overall distribution of the foraminifera in the present area, it may be observed that the temperature condition is within the tolerance for the thriving of foraminifera fauna throughout the year.

\section{Salinity}

Each benthic foraminifera species, has a specific limit of its tolerance to salinity besides other factors. In all sampling locations, the salinity does not show much variation due to mixing of water and due to bay nature of the coast (Table-2). But up to $1.5 \mathrm{~m}$ depth, is slightly decreased. Salinity increased at the depths of 5.5 and $8.5 \mathrm{~m}$ and species diversity also increased accordingly. 
Table-3: Distribution of ecological parameters, textural parameters, living, dead foraminifera off Kodiyakarai.

\begin{tabular}{|l|l|l|l|l|l|l|l|l|l|l|l|l|}
\hline Distance & $\begin{array}{l}\text { Depth } \\
\text { in } \mathrm{m}\end{array}$ & $\begin{array}{l}\text { Calcium } \\
\text { Carbonate }\end{array}$ & $\begin{array}{l}\text { Organic } \\
\text { matter }\end{array}$ & Salinity & Substrate & $\begin{array}{l}\text { Standard } \\
\text { Deviation }\end{array}$ & Mean & Skewness & Kurtosis & pH & $\begin{array}{l}\text { Dead } \\
\%\end{array}$ & $\begin{array}{l}\text { Living } \\
\%\end{array}$ \\
\hline 0.5 & 1.5 & 0.47 & 0.33 & 34.5 & $\begin{array}{l}\text { Silty } \\
\text { Sand }\end{array}$ & 0.501 & 2.518 & 0.028 & 1.075 & 6.500 & 99.29 & 0.71 \\
\hline 1.5 & 3 & 2.46 & 0.09 & 34.2 & $\begin{array}{l}\text { Silty } \\
\text { sand }\end{array}$ & 0.398 & 2.091 & -0.110 & 1.080 & 7.000 & 98.740 & 1.26 \\
\hline 3 & 5.5 & 3.33 & 0.33 & 35.67 & $\begin{array}{l}\text { Fine } \\
\text { Sand }\end{array}$ & 0.492 & 2.559 & -0.195 & 1.205 & 7.000 & 87.77 & 2.23 \\
\hline 4.2 & 6.7 & 19.47 & 0.28 & 35.85 & $\begin{array}{l}\text { Fine } \\
\text { Sand }\end{array}$ & 0.457 & 2.406 & 0.114 & 1.112 & 7.500 & 98.310 & 3.60 \\
\hline 5.5 & 7.5 & 7.7 & 0.09 & 35.2 & $\begin{array}{l}\text { Fine } \\
\text { Sand }\end{array}$ & 0.564 & 2.012 & 0.098 & 1.042 & 7.500 & 95.77 & 4.22 \\
\hline 6 & 8 & 7.22 & 0.05 & 35.44 & $\begin{array}{l}\text { Fine } \\
\text { Sand }\end{array}$ & 0.409 & 2.575 & 0.087 & 0.875 & 7.500 & 95.72 & 4.08 \\
\hline 6.5 & 8.5 & 8.14 & 0.14 & 35.3 & $\begin{array}{l}\text { Fine } \\
\text { Sand }\end{array}$ & 0.539 & 2.536 & -0.036 & 1.083 & 7.500 & 95.77 & 4.23 \\
\hline Average & & 6.97 & 0.19 & 35.31 & & 0.480 & 2.385 & -0.002 & 1.0676 & 7.214 & 95.91 & 2.90 \\
\hline
\end{tabular}

\section{Water Depth}

The effect of water depth is difficult to assess because other ecological factors vary with depth, like temperature, light intensity, pressure, oxygen etc. (Boltovskoy and Wright, 1976). For the present study, samples were collected from 0 to $15 \mathrm{~m}$ depth. The number of foraminiferal species is increased from $5.5 \mathrm{~m}$ depth may be due to the tidal fluctuation and shadow zone environment; the lesser number of species is observed up to the depth of $3.0 \mathrm{~m}$.

\section{Sand-Silt-Clay Ratio}

The textural attributes of sediment samples are either silty sand or clayey sand. Silty sand is predominant in deeper stations. The living foraminiferal populations are more abundant in silty sands.

\section{Organic matter}

The scatter plot of organic matter vs living species $(\mathrm{R}=0.377)$ shows positive correlation (Fig.5). Furthermore, the trend of organic matter vs carbonate content (Fig. 6) suggests that the drifting of sediment from the inner shelf regions due to littoral drift activities played a role in the contribution of carbonate shells. The percentage abundance of living species indicates a rise in the deeper station at Kodiyakarai and this may be due to oxygenated conditions prevailed at the location.

\section{Calcium Carbonate}

A lower amount of carbonate content at shallower depths in all the stations is noticed (Table-2). The scatter plot of carbonate content vs living species (Fig.7) shows the negative correlation $(\mathrm{R}=-0.16)$. It suggests that a weak relationship is maintained between carbonate content and living/dead species. 
Open access e-Journal

Earth Science India, eISSN: $0974-8350$

Vol. 7 (III), July, 2014, pp. 73 - 88

http://www.earthscienceindia.info/

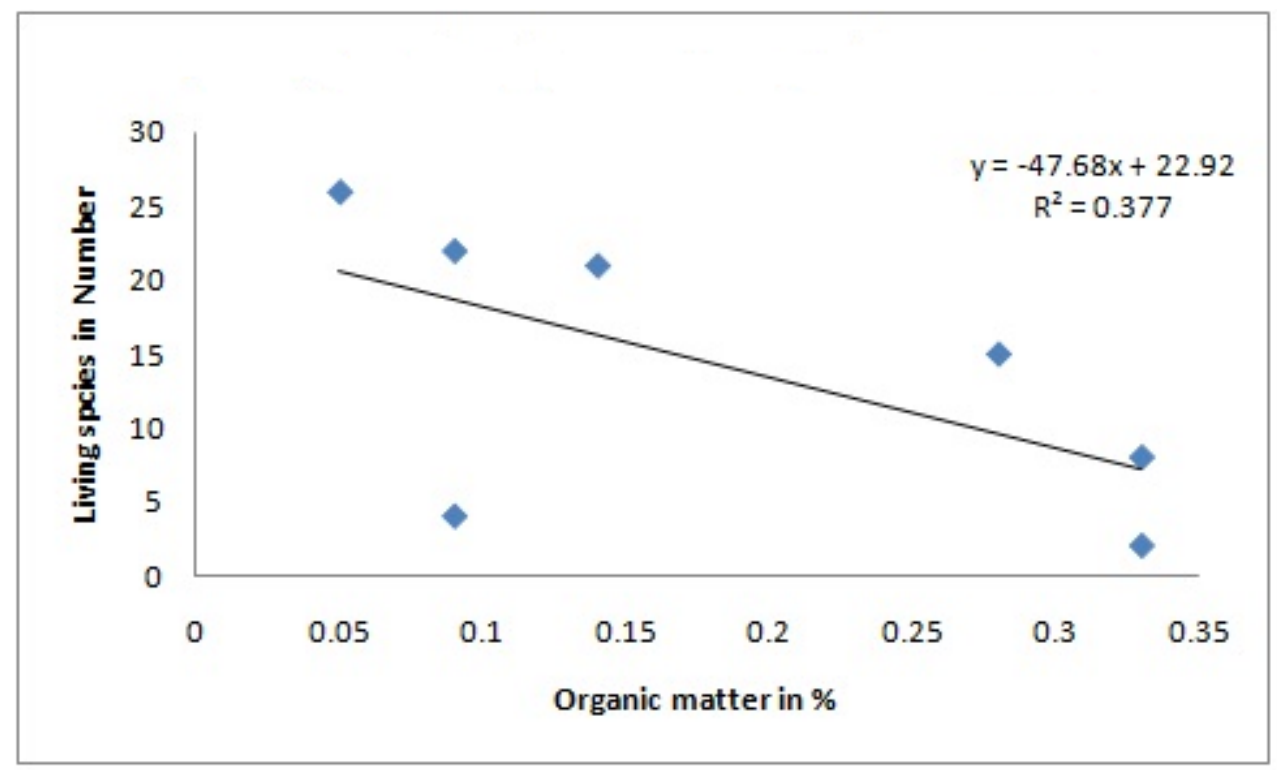

Fig. 5: Scatter plot of organic matter and living species.

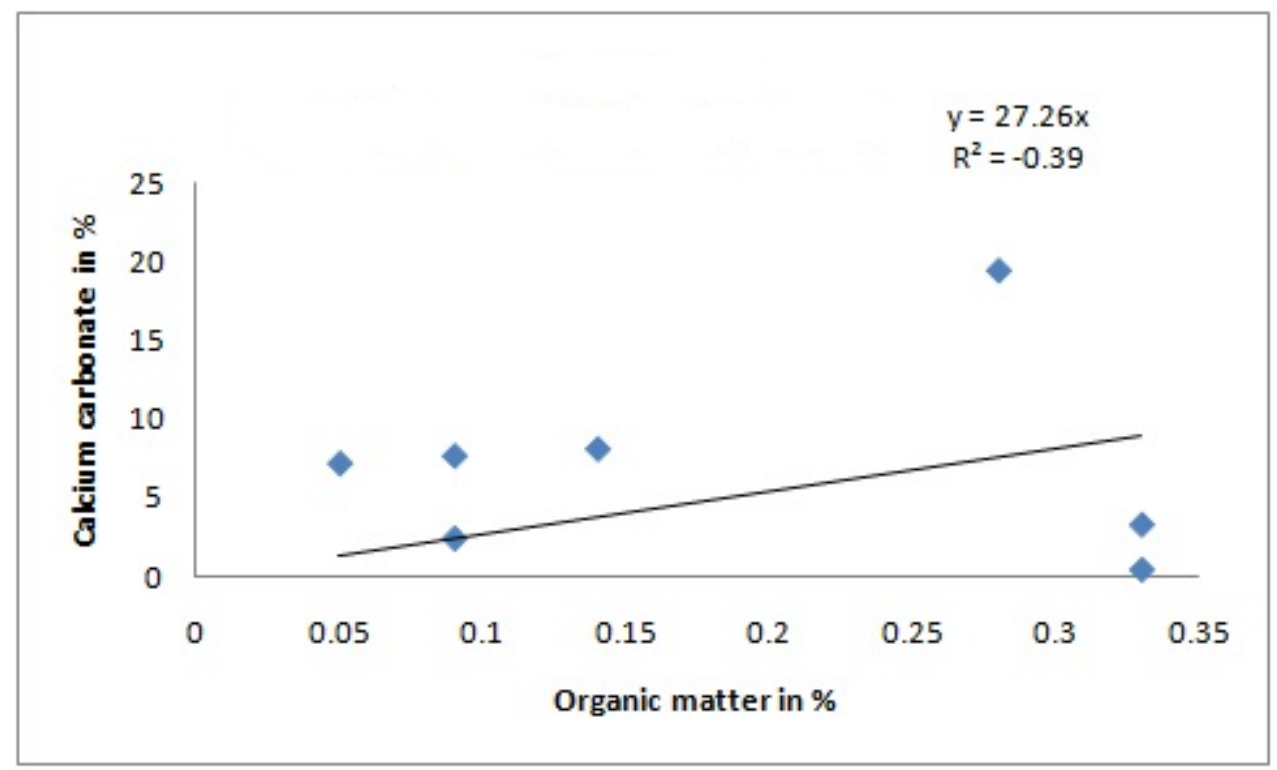

Fig. 6: Scatter plot of organic matter vs calcium carbonate. 


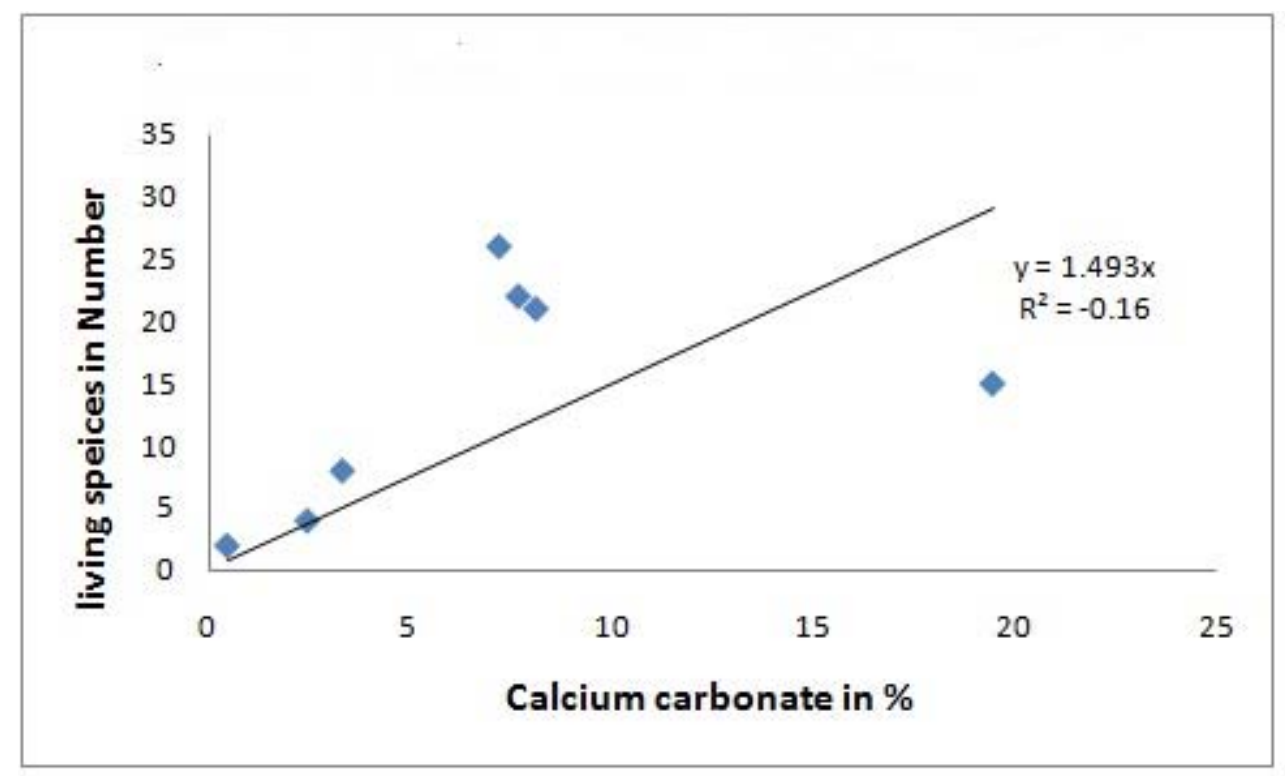

Fig. 7: Scatter plot of calcium carbonate vs living species.

\section{Discussion}

In total, 44 foraminiferal species belonging to 23 genus, 15 families, have been identified from 7 sediment samples collected off Kodiyakarai, Palk Strait (Plate- I to III). The majority of benthic foraminifera is reported to be dead, whereas live species are rarely reported. Out of the forty four species, ten species are abundant namely Ammonia beccarri, Elphidium macellum, E.incertum, E.crispum, Asterorotalia inflata, A.trispinosa, Nonionoides boveanum, Bolivina nobilus, Quinqueloqulina elongatum while others are in common and rare category. Due to wave shadow conditions and clayey substratum the $N$. boueanum and A.trispinosa occur frequently. The depth wise distribution of living specimens shows that the first three depths up to $3.0 \mathrm{~m}$ record $<10$ specimens. In spite of the presence of protective environment in Kodiyakarai the absence of more families may be attributed to clayey substrate.

Kodiyakarai records higher species diversity in spite of less depth and more protective environment in nature, and it may be ascribed to the continued connection with open sea with finer substratum and less turbid condition. The sizes of the foraminifera at these sampling locations are generally very small.

The low organic matter in Kodiyakarai in all the depths and particularly in deeper depths $(8.5 \mathrm{~m})$ is observed. Here the drifting currents move in anticlockwise direction and further the monsoonal currents enter from the channel with full strength. It is found to be a zone of unstable substratum having a number of minor channels conduit the fast moving currents and that hinder the settling of organic carbon. Moreover, it is observed that, with sheltered environment allowing the deposition of only fine sediments, pushed aside to the calm environment. The low energy 
condition is also accounted by the positive skewness prevailing in this region. It is supported by the earlier studies by Mohan et al., 2000.

The organic matter maintains a positive correlation $(\mathrm{R}=0.377)$ with distribution pattern of living species, in Kodiyakarai. It is rather difficult to assess the biomass contributed to the sediments from the living species, because abundance estimate was made on total specimen counts. The species are seen to be abnormally small in size. The small size $(0.12-0.10 \mathrm{~mm})$ suggests a lack of normal environment for healthy growth. Since, there is no free mixing of wave action, surface productivity must have been low and settling of biomass must have been predominantly less. Moreover, since, there is lack of oxygenated conditions, humus accumulation also must have been low (Dwivedi, et al., 1975). Above all, the living benthic foraminifera must have consumed whatever little organic matter available in the substratum for survival (Muray, 1991; Fontainer et al., 2002). Such activities have also been assumed to have given rise to low organic matter in this area, in spite of more number of living species, miniature in size.

The carbonate content is higher in $8 \mathrm{~m}$ water depths compared to less than $8 \mathrm{~m}$ depths. When the sediments are checked visually, a higher order of broken shells is noticed in that depth. Carbonate does not indicate any good correlation with living species. The carbonate shells have also been the product originated elsewhere, probably the drifted shell debris. It may also be due to the existing strong currents leading to non-deposition of terrigenous material and or to a limited terrigenous supply (Mohan and Rajamanickam, 1994).

The silty nature of samples at Kodiyakarai indicates the prevalence of calm environment allowing the drifted suspended load to get settled. It is supported by Ramasamy et al., (1998) who had calculated the accretion of sediments and the extent of land building activity in the Vedaranyam offshore area due to littoral currents seems to be happening at the rate of 29 meters/year. The sorting character at Kodiyakarai station looked displays poor sorting, though it establishes a protected calm environment. It may be presumed that the returning currents from spit through Sethubavachattiram would have disturbed the seabed before leaving the channel. Moreover, the broken shell remains as reflected from the high carbonate values may also give rise to poor sorting. The complete positive skewness of Kodiyakarai may be attributable to the low energy condition of deposition or otherwise the dominant influence of dune/ ridge sediments as noticed around the Vedaranyam ridge.

The dead specimens are more in all the sampling locations in Koddiyakarai. Only at these stations, the finest fractions of the sediment load seem to be brought by the currents. The nature of substratum also supplements this inference with the presence of silty sand at Kodiyakarai at all the depths. A larger deposit of dead specimens is normally expected at the point of outlet because of the interference of the incoming currents and the configuration of the coastline which directs the currents to pass out by the sides of the spit limb in the north by Vedaranyam spit. 


\section{Conclusions}

In total, 48 species belonging to 14 families and 22 genera were identified. Study suggests that fine sediments in Kodiyakarai are much favorable for thriving of foraminiferal species. Asterorotalia trispinosa is the most dominated species in this region followed by $A$. beccarii and E.crispum. The low salinity condition, less organic matter content and fine sediment texture are the major factors controlling foraminiferal distribution in Kodiyakarai region.

Acknowledgement: We sincerely acknowledge the University Grants Commission, for providing overall support by funding the Major project to the first author (UGC letter F.No.39-145/2010 (SR) dt.27th Dec- 2010). Authors are grateful to Prof. S.P. Mohan, Head of Department for providing necessary facilities. We sincerely express our thanks to the reviewer, for his valuable comments on the manuscript.

\section{References}

Boltovskoy, E. and Wright, R. (1976) Recent Foraminifera. Dr W. Junk, The Hague. 515 p.

Fontainer, C., Jorissen, F. J., Licari, L., Alexandre, A., Anschutz, P., Carbonel, P. (2002) Live benthic foraminiferal faunas from the Bay of Biscay: faunal density, composition, and microhabitats. Deep-Sea Res. Part1, v.49 (4), pp. 751-785.

Hayward, B.W. (1981) Foraminifera in the near shore sediments of Eastern bay of islands, northern New Zealand, TANE, v. 27, pp. 123-134.

Jackson, M. L. (1958) Soil Chemical Analysis. Prentice Hall, New York, 485p.

Jena, B. K., Chandramohan P. and Sanil Kumar, V. (2001) Long shore transport based on directional waves along north Tamil Nadu coast. India J. Coast. Res., v. 17, pp. 322-327.

Kumar, V. (1988) Ecology, distribution and systematic of recent benthic foraminifera from the Palk Bay, off Rameswaram, T. N. Unpublished Ph. D. Thesis, Bharatidasan University, India

Loveson, V. J., Rajamanickam, G.V. and Anbarasu, A. (1990) Remote Sensing application in the study of sea level variation along Tamil Nadu coast, India. In: G.V. Rajamanickam (ed.), Sea Level Variation and its Impact on Coastal Environment, Tamil University Press, Thanjavur, pp, 179-195.

Lowman, S.W. (1949) Sedimentary facies in Guld Coast. Am. Assoc. Petroleum Geologists, Bull. v. 33, no.12, pp.1930-1997.

Murray, J. W. (1991) Ecology and palaeoecology of benthic foraminifera. Longman Scientific and Techinical, Harlow. pp. 316-322.

Mohan, P.M. and Rajamanickam, G.V. (1994) Organic matter and carbonate in the southwest continental shelf. Jour. Geol. Soc. India, v. 44, pp. 575-580.

Mohan, P. M., Shephard, K., Angusamy, N., Suresh Gandhi, M. and Rajamanickam, G.V. (2000) Evolution of quaternary sediments along the coast between Vedaranyam and Rameswaram. J. Geol. Soc. India, 56: 271-283.

Nisha, N. R. and Singh, A. D. (2012) Benthic foraminifera biofacies on the shelf and upper continental slope off North Kerala, (Southwest India). Jour. Geol. Soc. India, v.80, pp.783801.

Ragothaman, V. (1974) The study of foraminifera off Porto Novo, Tamil Nadu State. Unpublished Ph. D. Thesis, University of Madras. 
Open access e-Journal

Earth Science India, eISSN: $0974-8350$

Vol. 7 (III), July, 2014, pp. 73 - 88

http://www.earthscienceindia.info/

Rajeshwara Rao, N. (1998) Recent foraminifera from innershelf sediments of the Bay of Bengal off Karikatukuppam near Madras. South India. Unpublished Ph. D. Thesis, University of Madras.

Ramasamy, S.M., Ramesh, D., Paul, M.A., Kusumgar, S. and Yadhava, M. A. (1998) Rapid land building activity along Vedaranyam coast and its possible implications. Curr. Sci., v. 75, pp. 884-886.

Renata Szareka, Wolfgang, Kuhntb, Hiroshi, Kawamurac, Hiroshi, Kitazatoa (2006) Distribution of recent benthic foraminifera on the Sunda Shelf (South China Sea). Marine Micropaleontology, v. 61, pp. 171-195.

Sanil Kumar, V., Chandramohan, P., Ashok Kumar, K., Gowthaman, R. and Pednekar, P. (2000) Long shore currents and sediment transport along Kannirajapuram Coast, Tamilnadu, India. Jour. Coastal Research, Washington D.C., v. 16(2), pp. 247-254.

Sanil Kumar, V., Anand, N. M. and Gowthaman, R. (2002) Variation in near shore processes along Nagapattinam coast, India. Curr. Sci., v. 82, pp. 1381-1389.

Shanti Devi, R. and Rajamanickam, G.V. (2000) Distribution of coastal landforms between the coast of Adirampattinam and Nagapattinam, Tamil Nadu. Ind. J. Geomorph., v. 5, pp. 137160.

Sundararajan, M. and Usha Natesan (2010) Environmental Significance in recent sediments along Bay of Bengal and Palk Strait, East coast of India: A Geochemical approach. Int. J. Environ. Res., v. 4 (1), pp. 99-120.

Sundararajan, M., Usha Natesan, Babu, N. and Seralathan, P. (2009) Sedimentological and Mineralogical Investigation of Beach Sediments of a Fast Prograding Cuspate Foreland (Point Calimere), Southeast Coast of India. Research Journal of Environmental Sciences, v. 3, pp. 134-148.

Suresh Gandhi, M (1999) Micropaleontology (Benthic foraminifera) study on the depositional environment of Palk Strait, East coast of India, Ph.D thesis submitted to Tamil University, Thanjavur, $180 \mathrm{p}$. 
Table-2: Distribution of foraminifera off Kodiyakarai (in numbers).

\begin{tabular}{|c|c|c|c|c|c|c|c|c|c|c|c|c|c|c|c|c|}
\hline \multirow[t]{3}{*}{ S/No } & & Beach & \multicolumn{2}{|c|}{ K1 } & \multicolumn{2}{|c|}{$\mathrm{K} 2$} & \multicolumn{2}{|c|}{ K3 } & \multicolumn{2}{|c|}{ K4 } & \multicolumn{2}{|c|}{ K5 } & \multicolumn{2}{|c|}{ K6 } & \multicolumn{2}{|c|}{ K7 } \\
\hline & \multirow[t]{2}{*}{ Species } & Depth & \multicolumn{2}{|c|}{$1.5 \mathrm{~m}$} & \multicolumn{2}{|c|}{$3.0 \mathrm{~m}$} & \multicolumn{2}{|c|}{$5.5 \mathrm{~m}$} & \multicolumn{2}{|c|}{$6.7 \mathrm{~m}$} & \multicolumn{2}{|c|}{$7.5 \mathrm{~m}$} & \multicolumn{2}{|c|}{$8.0 \mathrm{~m}$} & \multicolumn{2}{|c|}{$8.5 \mathrm{~m}$} \\
\hline & & & $\mathrm{L}$ & $\mathrm{T}$ & L & $\mathrm{T}$ & $\mathrm{L}$ & $\mathrm{T}$ & $\mathrm{L}$ & $\mathrm{T}$ & $\mathrm{L}$ & $\mathrm{T}$ & $\mathrm{L}$ & $T$ & $\mathrm{~L}$ & $\mathrm{~T}$ \\
\hline 1 & Ammobaculites exiguus & & & & & & & & & 2 & & 2 & & & & \\
\hline 2 & Textularia agglutinans & 2 & & 3 & & 2 & & & & & & & & & & \\
\hline 3 & Textularia bocki & & & & & 2 & & 1 & & & & & & & & \\
\hline 4 & T porrecta & 1 & & 2 & & 1 & & 1 & & & & & & & & \\
\hline 5 & Spiroloculina communis & & & 4 & & 3 & & 2 & 0 & 4 & 0 & 4 & 0 & 2 & & 7 \\
\hline 6 & S. nobilus & 1 & & 1 & & & & & & & & & & & & \\
\hline 7 & S. depressa & & & 6 & & 4 & & 3 & & 2 & & 1 & & & & \\
\hline 8 & S.indica & 2 & & 2 & & 1 & & & & & & & & & & \\
\hline 9 & Spiroloculina orbis & & & & & 2 & & & & 6 & & & & 4 & & 3 \\
\hline 10 & Quinqueloculina cultrata & & & & & & & & & & & & & & & \\
\hline 11 & Q.costata & & & & & & & & & & & & & & & \\
\hline 12 & Q. lamarckiana & 2 & & & & & & & & 4 & & & & 6 & & \\
\hline 13 & Q.seminulum & & & 2 & & & & 1 & & & & & & & & \\
\hline 14 & Q.strigillata & & & & & & & 2 & & & & 1 & & & & \\
\hline 15 & Q.tropicalis & & & & & 3 & & & & 5 & 1 & 4 & 2 & 6 & 2 & 7 \\
\hline 16 & Miliolinella circularis & & & & & 2 & & & & 3 & & & & 4 & & \\
\hline 17 & M.pyrgoformis & 1 & & 3 & & & & 4 & & & & 4 & & 4 & & \\
\hline 18 & Legina perlucida & & & & & & & & & & & & & 2 & & 2 \\
\hline 19 & Bolivina durandi & & & & & & & & & 2 & & 3 & 1 & 3 & 1 & 3 \\
\hline 20 & B. lobata & & & & & & & & & & & & & & & \\
\hline 21 & B.spathulata & & & & & & & 1 & & & & & & 2 & & 2 \\
\hline 22 & B.ordinaria & & & & & & & & & 2 & & 1 & & 2 & & 2 \\
\hline 23 & Loxostomina limbata & & & 2 & & & & & & 1 & & & & & & \\
\hline 24 & Reusella simplex & & & & & & & & & & & 2 & & 3 & & 3 \\
\hline 25 & Shiphouvigerina virgula & & & & & & & & & & & & & 1 & & 1 \\
\hline 26 & Triloculina tricarinata & 1 & & 2 & & & & & & & & & & & & \\
\hline 27 & T. trigonula & & & 2 & & & & 4 & & & & 6 & & 6 & & 2 \\
\hline 28 & Globigerina bulloides & & & & & & & & & 2 & & 2 & & 2 & & 2 \\
\hline 29 & Eponides repandus & & & 2 & & & & 2 & & 2 & & & & & & \\
\hline 30 & Cibicides lobatulus & & & & & & & & & & & 4 & & & & \\
\hline 31 & Amphistegina radiata & 2 & & & & 6 & & 4 & & & & 4 & 1 & 3 & & \\
\hline 32 & Nonion elangatum & & & & & & 2 & & & 3 & 1 & 8 & 2 & 6 & 2 & 6 \\
\hline 33 & N.scaphum & & & & & & & & & 1 & & 4 & & 4 & & 4 \\
\hline 34 & Nonionellina labradorica & & & & & & & 1 & & & & & & 2 & & 2 \\
\hline 35 & Nonionoides boueanum & & & & & & & & & 3 & & 8 & & 7 & 2 & 8 \\
\hline
\end{tabular}


Open access e-Journal

Earth Science India, eISSN: 0974 - 8350

Vol. 7 (III), July, 2014, pp. 73 - 88

http://www.earthscienceindia.info/

\begin{tabular}{|c|c|c|c|c|c|c|c|c|c|c|c|c|c|c|c|c|}
\hline 36 & Pararotalia calcar & 2 & & & 1 & & 1 & 6 & 2 & 12 & 1 & 13 & 2 & 22 & 2 & 12 \\
\hline 37 & P. nipponica & 4 & 1 & 13 & & 16 & & 12 & 2 & 14 & 3 & 12 & 2 & 22 & & 18 \\
\hline 38 & Ammonia beccarii & 14 & 1 & 28 & 2 & 32 & 3 & 32 & 5 & 30 & 4 & 46 & 5 & 57 & 2 & 43 \\
\hline 39 & A. dentata & 1 & & 18 & & 6 & & 12 & 1 & 14 & 2 & 3 & 2 & 22 & 2 & 34 \\
\hline 40 & A. tepida & 2 & & 4 & & 3 & & 6 & 1 & 6 & 1 & 9 & 2 & 14 & 2 & 14 \\
\hline 41 & Asterorotalia trispinosa & 14 & & 156 & 1 & 202 & 2 & 224 & 3 & 258 & 6 & 324 & 4 & 387 & 4 & 298 \\
\hline 42 & Elphidium? & 1 & & 6 & & 8 & & 10 & 1 & 12 & 1 & 14 & 1 & 16 & & \\
\hline 43 & E. crispum & 1 & & 21 & & 18 & & 17 & & 14 & 2 & 26 & 2 & 22 & 2 & 22 \\
\hline 44 & E. discoidale & & & & & & & 4 & & & & 6 & & 2 & & \\
\hline 45 & E. delicatulum & & & 1 & & & & 3 & & & & 2 & & 1 & & \\
\hline 46 & E. norvangi & & & 1 & & 2 & & & & & & 6 & & 1 & & \\
\hline 47 & Assilina ammonoides & 2 & & 3 & & & & 4 & & & & 1 & & 2 & & 2 \\
\hline 48 & Parallilna hispudila & & & & & 4 & & 2 & & 2 & & 1 & & & & \\
\hline & TOTAL & 53 & 2 & 282 & 4 & 317 & 8 & 358 & 15 & 404 & 22 & 521 & 26 & 637 & 21 & 497 \\
\hline & $\begin{array}{l}\text { Total Number of } \\
\text { Individuals }\end{array}$ & 17 & 2 & 22 & 3 & 21 & 5 & 25 & 7 & 24 & 10 & 29 & 12 & 31 & 10 & 23 \\
\hline & Living/ Dead Ratio & & \multicolumn{2}{|c|}{0.7} & \multicolumn{2}{|c|}{1.26} & \multicolumn{2}{|c|}{2.23} & \multicolumn{2}{|c|}{3.71} & \multicolumn{2}{|c|}{4.22} & \multicolumn{2}{|c|}{4.39} & \multicolumn{2}{|c|}{4.22} \\
\hline & Dead Species \% & & & 99.29 & & 98.7 & & 97.8 & & 96.31 & & 95.77 & & 95.92 & & 95.8 \\
\hline & Living Species \% & & 0.71 & & 1.26 & & 2.23 & & 3.6 & & 4.22 & & 4.08 & & 4.23 & \\
\hline
\end{tabular}




\section{PLATE-I}

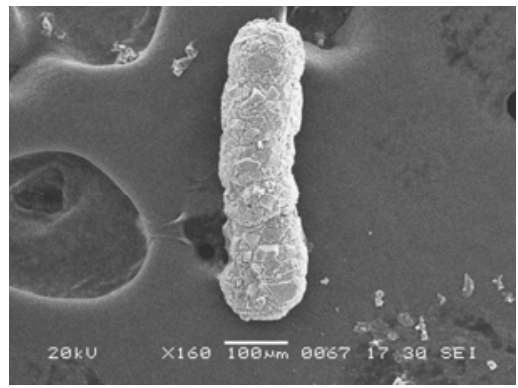

Ammobaculites exiguus (AV)

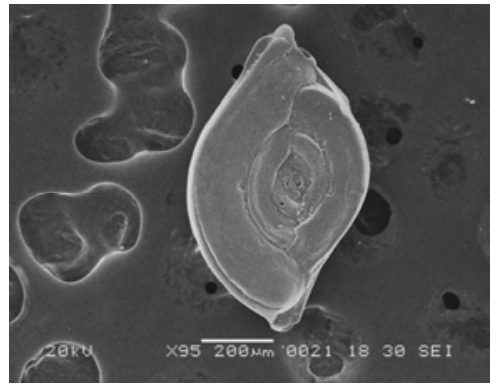

spiroloculina communis(SV)

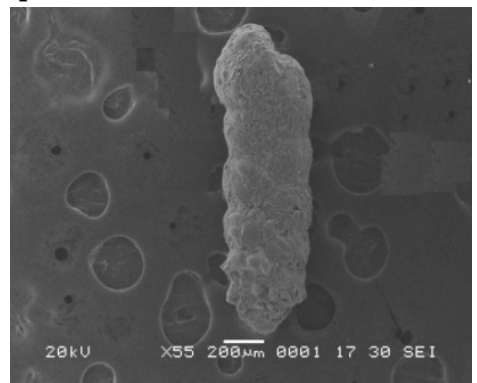

T.Porrecta(SV)

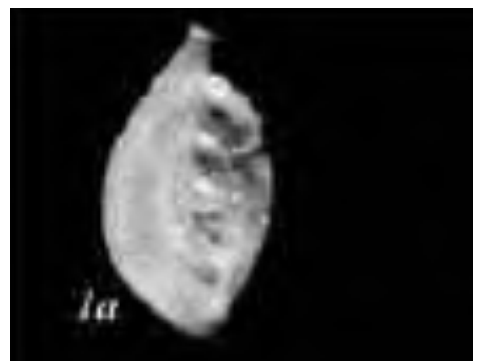

Spiroloculina nobilis ( SV)

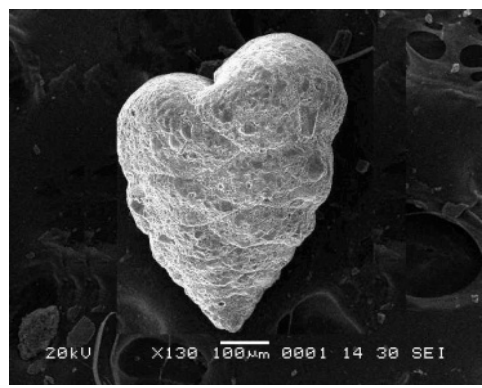

Textularia agglutinans (SV)

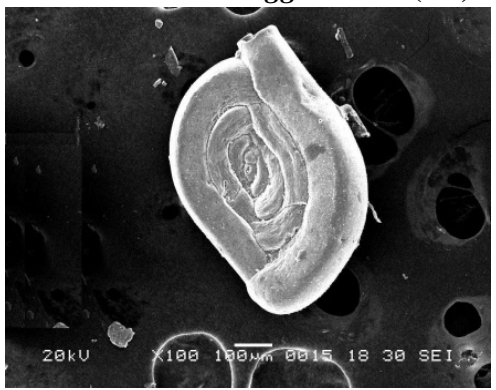

S.depressa (SV)

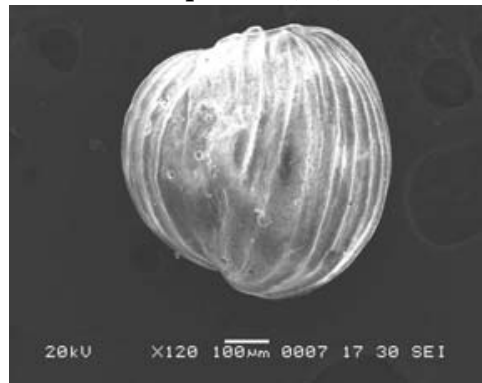

Q.costata (SV)

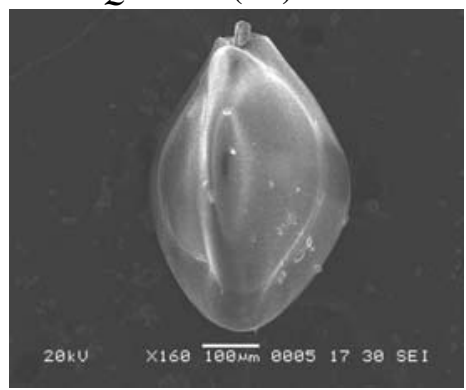

T. tricarinata (SV)

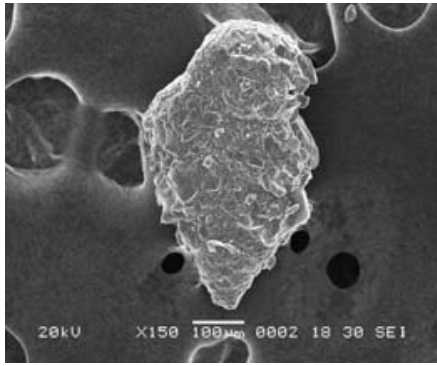

Textularia bocki (SV)

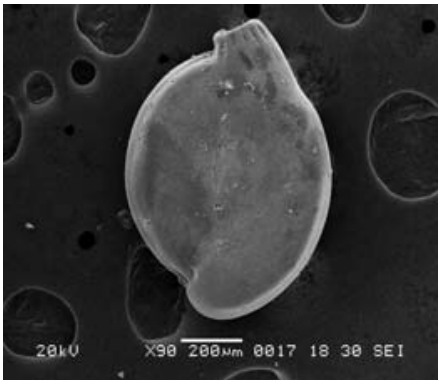

S.orbis ( SV)

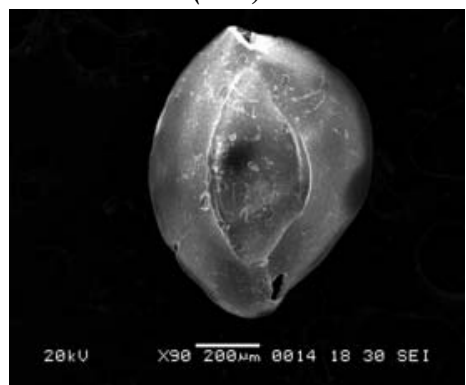

Q. Iamarckiana (SV)

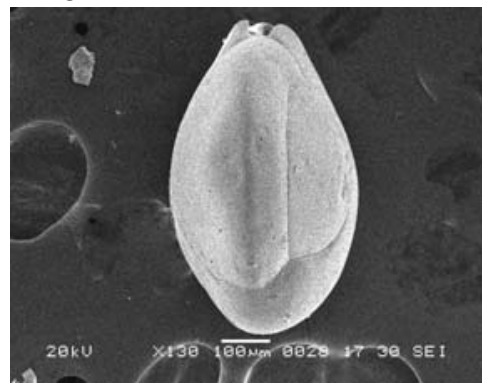

T. trigonula ( SV) 
Open access e-Journal

Earth Science India, eISSN: 0974 - 8350

Vol. 7 (III), July, 2014, pp. 73 - 88

http://www.earthscienceindia.info/

\section{PLATE-II}
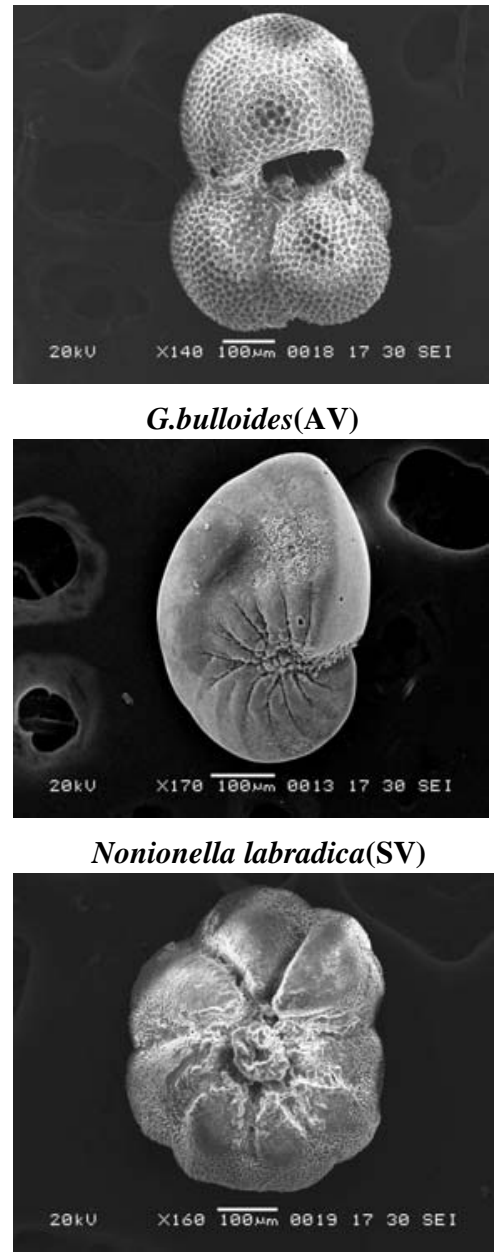

Pararotalia nipponica (AV)

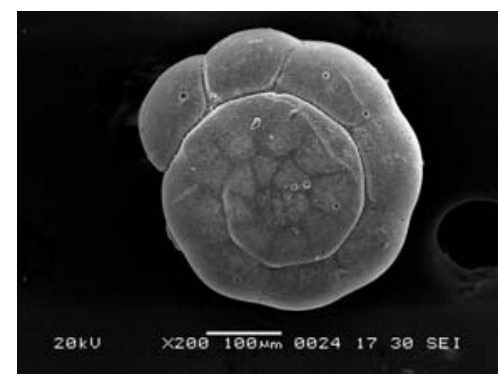

Ammonia tepida(DV)

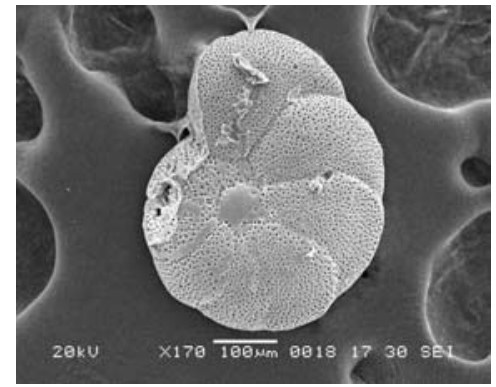

Cibicides lobatulus(DV)

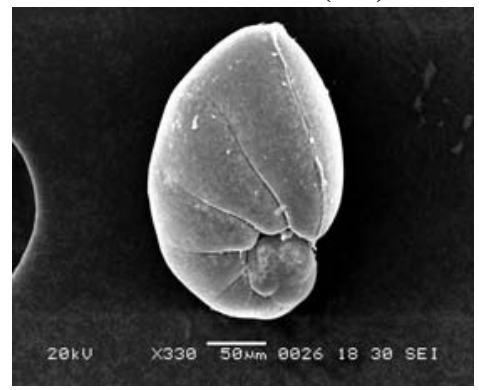

Nonionoides boueanum (SV)

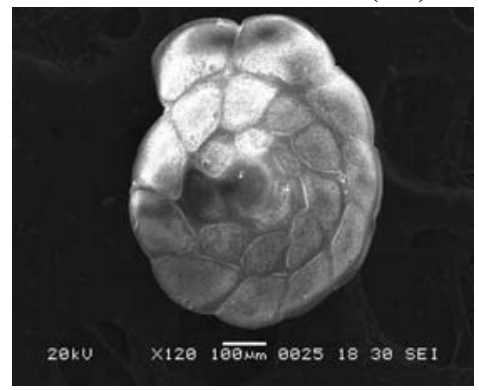

Ammonia beccarii(DV)

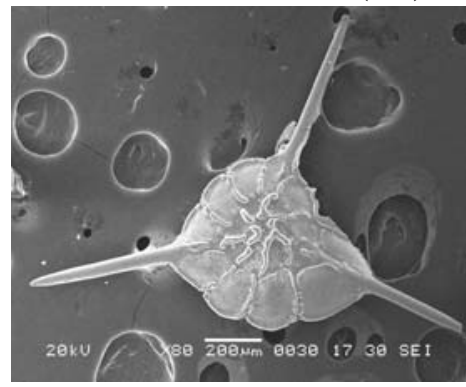

Asterorotalia trispinosa(DV)

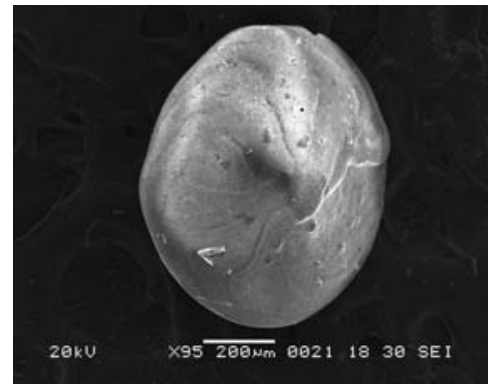

Amphistegina radiate (DV)

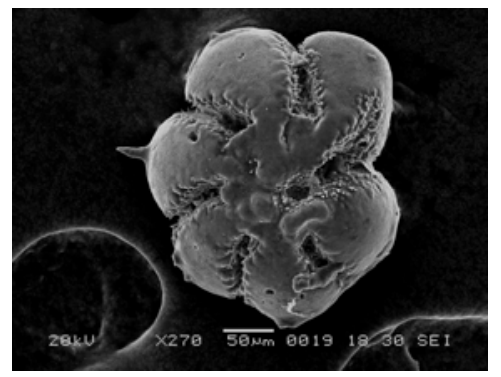

Pararotalia calcar(VV)
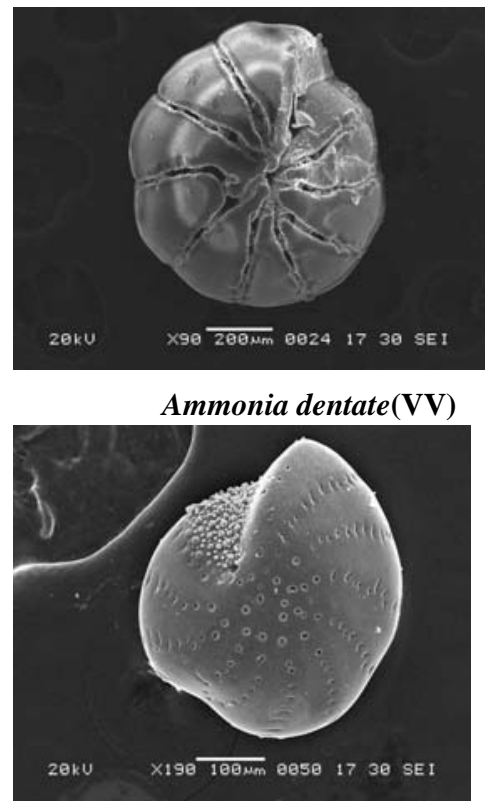

Elphidium norvangi ( DV) 


\section{PLATE-III}

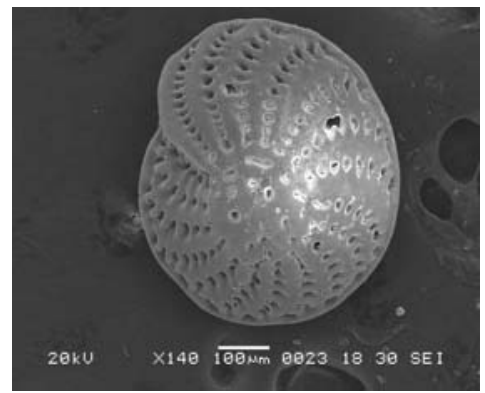

E. crispum(DV)

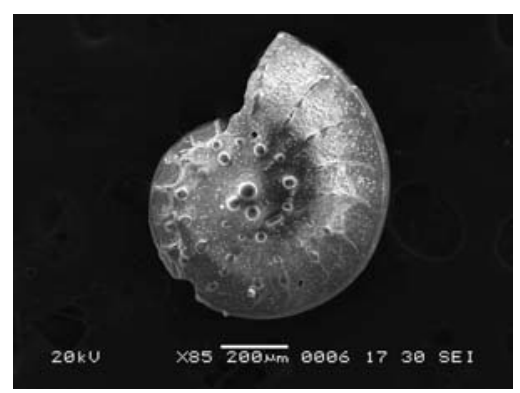

Assilina ammonoides (DV)

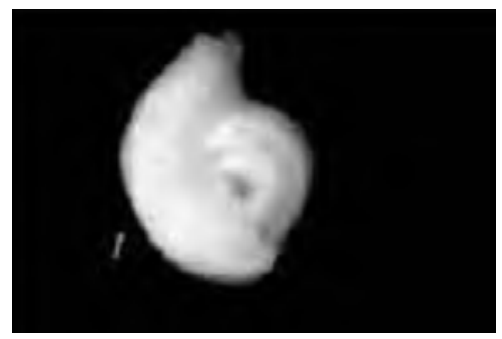

Q.cultrata (SV)

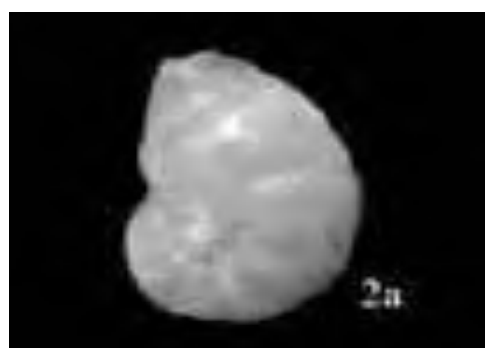

Nonion scaphum (DV)

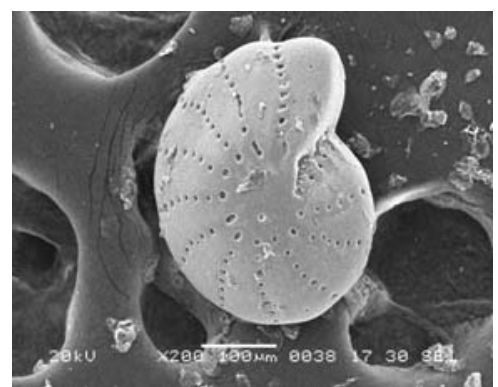

E. discoidale(DV)

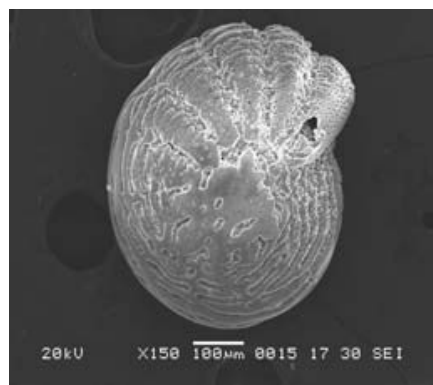

Parallina hispidula(DV)

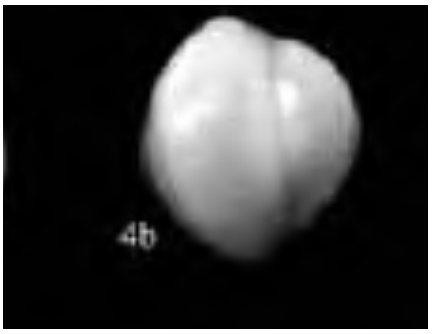

Q.strigillata(SV)

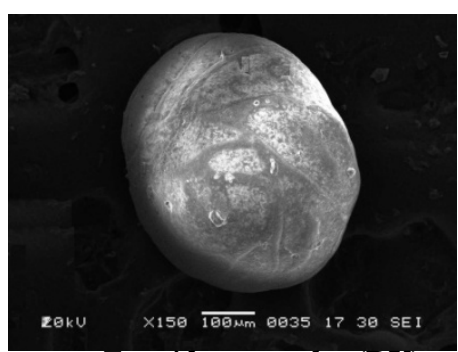

Eponides repandus (DV)

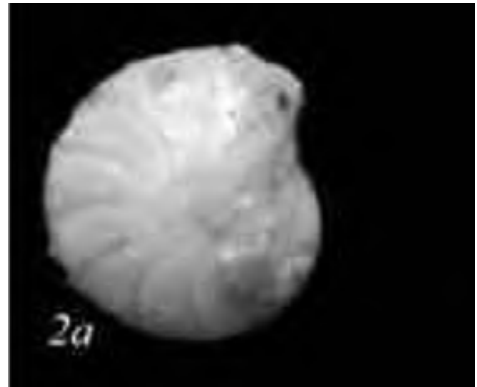

E.delicatulam(DV)

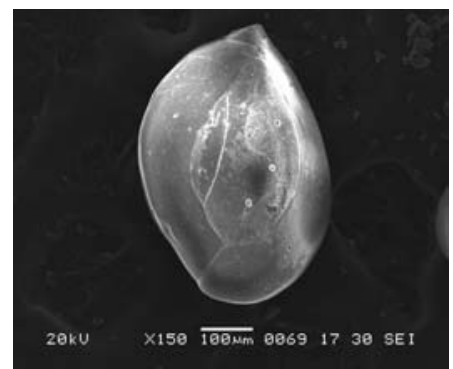

Q.seminulum(SV)

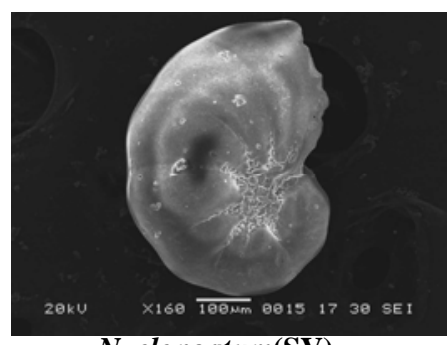

N. elongatum(SV)

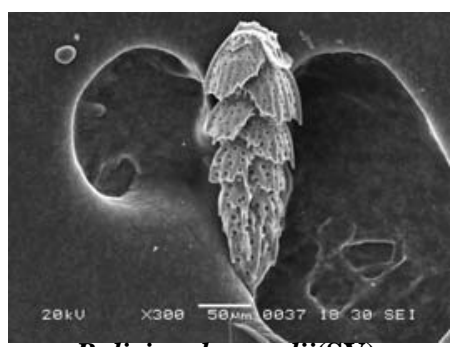

Bolivina durrandit(SV)

(Received: 06.09.2013; Accepted: 15.07.14) 